\title{
Chinua Achebe's Things Fall Apart and the Role of Women in Igbo Traditional Religious Culture
}

\author{
Udeagha Nduka1, Nwamah Grace Ozioma² \\ ${ }^{1}$ Department of Religion and Cultural Studies, University of Nigeria, Nsukka, Nigeria \\ ${ }^{2}$ Nwamah Grace Ozioma, Department of Religious Studies, Imo State University, Owerri, Nigeria \\ Email: andyudeagha@yahoo.com,grace.nwamah@unn.edu.ng
}

How to cite this paper: Nduka, U. and Ozioma, N.G. (2019) Chinua Achebe's Things Fall Apart and the Role of Women in Igbo Traditional Religious Culture. Open Journal of Social Sciences, 7, 272-289. https://doi.org/10.4236/jss.2019.712020

Received: January 27, 2019

Accepted: December 17, 2019

Published: December 20, 2019

Copyright $\odot 2019$ by author(s) and Scientific Research Publishing Inc. This work is licensed under the Creative Commons Attribution International License (CC BY 4.0).

http://creativecommons.org/licenses/by/4.0/

cc) (i) Open Access

\begin{abstract}
The paper examines the role of women in Igbo religious culture as portrayed by Chinua Achebe in his classic novel, Things Fall Apart. It explores the position of women in Igbo cultural practice by highlighting the valuable and indispensable role of Igbo women as derived from the novel. Achebe's portraiture of the feminine gender has continued to draw a lot of attention as a result of their largely perceived degrading roles. This was done by a critical analysis of the novel, Things Fall Apart, which ultimately formed the fulcrum of the study, as well as other relevant documents. Based on the key religious, educational, socio-cultural and other roles of women as derived from the novel, the paper finds out that contrary to the general notion that women are to be seen and not to be heard, women are actually seen and heard especially, as a result of their indispensable roles in the traditional Igbo society. The place of women in Igbo cultural society is pivotal and very critical in the sustenance and continuance of human society.
\end{abstract}

\section{Keywords}

Things Fall Apart, Women, Role, Igbo Traditional Society, Religious Culture

\section{Introduction}

Chinua Achebe in Things Fall Apart highlighted varying Igbo cultural values. Though the novel was essentially about the culture contact and conflict between the Igbo Africa and the European whites, among other values in the Igbo culture, the theme of gender is evidently highlighted. The Roles of gender was stridently captured and featured in the tale in a manner that it should be critically examined. In fact, the concept of masculinity and femininity were conspicuously highlighted that individual tasks, farm crops and societal crimes were yet diffe- 
rentiated in terms of gender qualities and classifications. As an instance, cultivation of those crops that require more energy like yam tubers and activities such as splitting of firewood were the reserved of men. Achebe's portraiture of the feminine gender has continued to draw a lot of attention as a result of their largely perceived undignified roles in the traditional Igbo society. The interest of this study is chiefly to reexamine the role of women in Igbo traditional society as was portrayed by Achebe.

Unoka, the father of Okonkwo is portrayed as a derisive scorn of the community, being lazy, poor and a disappointing failure in life. He was not a courageous man. "He was in fact a coward and could not bear the sight of a blood" [1] (p. 2). As a result of the disappointing life of his father who could barely fend for his small family, Okonkwo was patently ashamed of his father and wanted to be an entirely different man. From his father's unsatisfactory experiences, he was intensely overwhelmed with fear of failure. He sought to be a man whose prominence will resonate throughout the nine villages of Umuofia community and beyond. He is indeed described as a man whose "fame rested on solid personal achievements" (p. 3). He is therefore, portrayed in sharp contrast with the father, Unoka. In pole apart character dissimilarities, Okonkwo cut the figure of a brave and courageous man, who "...was not afraid of war", he was rather, "a man of action, a man of war. Unlike his father, he could stand the look of blood" [1] (p. 3). In other to maintain and sustain his solemnly desired traits of manliness and assiduousness that were conspicuously deficient in his father's persona, Okonkwo therefore became not just a rich and brave man, but a fearsome terror to people around him especially, among members of his household. His wives were unceasingly at the receiving end of his uncontrollable raging fury. As a result of his overt loathing for feminine qualities and woman-like dispositions, women were largely construed as being relegated in the Igbo traditional religious culture. The manner Chinua Achebe presented women in the novel makes it appear as if Igbo women are largely relegated to the background in the traditional scheme of things.

Apparently, this is mostly for the verity that Okonkwo beats his wives at every twist and turn of his rage, thereby demonstrating manliness and his loathsomeness for feminism and weaknesses. It was as if the Igbo culture encourages wife beating. Consequently, Okonkwo's household members were constantly at the receiving end of his fiery temper and scores of hostile assaults. Okonkwo is a man filled with violent outbursts that mostly find an outlet in his family members. His wives were predominantly at the epicenter of his domestic violence and turned out the principal victims of sadistic battering. They variously suffered Okonkwo's willful intimidation, physical, psychological and emotional tortures. Apart from brutal threats and scary attempts, there are two major instances in the novel where Okonkwo beats his third and second wives.

On one hand, Ojugo, Okonkwo's third wife was beaten because she failed to perform one of the important roles of women in the Igbo traditional culture which is cooking. She went to plait her hair and could not return early enough to 
cook the afternoon meal. On the other hand, he beats up Ekwefi, his second wife for merely cutting off a few leaves of his banana tree to wrap some food. Okonkwo cantankerously alleged that Ekwefi had killed the banana tree, which as a matter of fact was very much alive. This left Ekwefi and her only daughter, Ezinma weeping. After the brutal beating, he also nearly dispatched Ekwefi to the great beyond with his gun, when in a manner of a sour countenance she glumly muttered about "guns that never shot" (p. 31). Okonkwo edgily unleashes his fury at the slightest provocations. He beats them not just as a form of discipline but out of the rabid uncontrollability of his smoldering rage, uncouth demonstration of masculinity and man's superiority over women. He seemed to be overshadowed by superiority complex that he could not devise other means of addressing household issues. He always resorts to intimidation and violence. He hardly shows emotion and avoids being seen as a woman; rather he promotes tales of war and maintains his pride, the show of strength and courage.

Nevertheless, on one of the abusive occasions, Okonkwo was relatively provoked to what Achebe describes as "justifiable anger" (p. 23). Ojugo, the youngest wife could also be "at fault" as observed by Ezeani, the priest of the earth goddess. But Okonkwo, instead of containing his abusive instincts, went ahead to beat Ojugo during the sacred "Week of Peace". Among many other traditional Igbo men, such should not have translated to utter beating and committing offence of mammoth consequences that was capable of ruining the entire clan. Okonkwo so much abused his wives to the degree he offended the ancestors and gods of the land.

Consequently, most of the people who studied the place of women in the Igbo traditional society appear to observe it in the negative. They typically see women as solely second class to men, who have little or virtually nothing to contribute in the largely patriarchal Igbo traditional society. They strongly maintain that "women are to be seen but not to be heard" [2] [3] [4]. Some of them derived such outright negative perception about the place of Igbo women from the novel Things Fall Apart. They rather highlight the patrilineal nature of the Igbo society, drawing more strength from the manliness and suppressive nature of Okonkwo to his wives, who is eventually the protagonist of the novel. But, Achebe evidently highlighted the indispensable values and roles of women in the Igbo culture. The attempt in this paper is therefore, to highlight the prime roles of women in Igbo culture as also derived from Things Fall Apart. They are discussed under the following headings:

- The Igbo Traditional Society

- The Role of Bearing Children

- Women as Children Educators

- Religious Roles

- Cooks and Caregivers

- Economic and Supportive Role

- Bridge Building Roles

- Significant of the Study in Promoting Social Progress 
- Limitations of the Study

- Conclusion

\section{The Igbo Traditional Society}

Achebe's Things Fall Apart is a literary mirror of the traditional Igbo society. It demonstrates that even prior to the advent of the Whiteman or contacts with the outside world, the Igbo already had a well-established belief system and socio-cultural patterns for their continued existence. These are thoughts, patterns and practical existential guides of the Igbo forebears that are passed on to successive generations.

The traditional Igbo believe that there is one creator God, Chineke or Chiukwu. He is the Supreme Being, who created and appointed numerous other deities and spirits as His ministers. Responding to Mr. Brown, a missionary in Umuofia, Akuna clarified the Igbo belief, "you say that there is one supreme God who made heaven and earth, ... we also believe in Him and call HimChukwu. He made all the world and the other gods" [1] (pp. 142-143). The religion recognizes other deities in contrast with the monotheistic model of the European missionaries. These deities are in charge of various departments of the people's life. Ala, the earth goddess, is in charge of land and fertility, ifejioku is the deity of yam, etc. It is with this Igbo traditional religious perspective that an old man asked the missionaries in Umuofia, "which is this god of yours, he asked, the goddess of the earth, the god of the sky, Amadioha of the thunderbolt or what?" [1] (p. 117). These minor deities act as the intermediaries between the people and God. They are constantly appeased to work in favour of man because ignoring them could cause individual harms and wreck communal havocs when they are sorely provoked. The traditional Igbodesire and aspire to live peacefully with nature and the gods. Igbo traditional religion exerts overwhelming influence on various aspects of the people's lives. A man's behaviour largely affects other members of the community. An individual may commit an offence against the earth goddess and it will result in the punishment of the entire clan, not just the offender, except she is appropriately placated.

The ancestors who have passed through the earth to the ancestral world are considered an integral part of the family. Graduating to the desirable status of ancestors imbues on them the supernatural powers to influence deities of the community and other forces of nature especially, in favour of their living families. Likewise any family member that tends to obstruct the peace or harmonious existence of the family is commensurably punished by the ancestors. They are therefore, constantly remembered and revered in order to curry their favour and gladden them in playing their imperative roles. The ancestors are not considered dead because they help to maintain household relationships and are believed to possess wonderful insight that tremendously impart on the living. The ancestors who manifested as the egwugwu in Things Fall Apart are so essential to the social wellbeing of the living. 
The Igbo also believe in the concept of chi. Using Okonkwo in describing the concept of chi in Things Fall Apart, Achebe says that "At the most one could say that his chi or personal god was good. But the Ibo people have a proverb that when a man says yes his chi says yes also. Okonkwo said yes very strongly; so his chi agreed" [1] (p. 21). Suffice it to say that one can influence his chi and destiny through a resilient demonstration of willpower and dint of hard work. Okonkwo assiduously worked hard to become one of the most respected men in his clan. Igbo culture encourages hard work and abhors laziness. They ensure that they train their family members in the way of farming and hard work.

The traditional Igbo society is agrarian. They were mostly farmers. They farm many crops including yam. Yam is symbolically significant that it is considered as the king of crops and therefore, celebrated in the event of new yam festival throughout Igboland. Strong indicators of success and influence in the traditional Igbo society include possessing numerous wives and children, farm lands, bountiful yam harvests and other farm products, titles and other heroic accomplishments. Nwosu (2002) observes that a wealthy man was also a man of property and that "it was from the proceeds of a man's property that he secures membership of a titled society" [5] (p. 237). In the traditional Igbo society, an individual can achieve success and fame by being a great farmer, medicine man, hunter, craftsman, warrior, etc.

Igbo pre-colonial clans like the Umuofia are largely polygamous. The more wives a man marries the richer he becomes. Most men married more than one wife. The first wife is the senior and most respected and honoured. She enjoys other principal and traditional privileges among other wives in a family. The children help to work in the farms and keep the animals. The Igbo is a patriarchal society, where the socio-cultural traditions appear to be dominated by the male gender through paternal power. The Igbo largely trace patrilineal descent and a man of worth leaves inheritance to his children. Unlike, Okonkwo who got nothing from his lazy father, Unoka, the children of a wealthy man get the father's support or inherit the father's wealth and start off a life of their own with it. They are members of extended families. Each member of the family has roles to play according to their age and gender.

The Igbo traditional society thrives on community-oriented life. This underlines the philosophical principle of "igwebuike" (unity is strength). An individual is integrated in the community in a manner that the community gives meaning to an individual's existence. They share deep sense of communalism and solidarity. They act like one; that is what Obierika meant when he referred to the disintegrating effects of the Whiteman's activities and soberly regretted thus; "Now he has won our brothers, and our clan can no longer act like one" [1] (p. 141). Among the traditional Igbo, there is high sense of oneness, togetherness and cohesiveness. The traditional Igbo society thrives in a mutually chained relationship, in that what affects one affects another. That is why like Okonkwo did, when a man commits a crime it might affect other members of the commu- 
nity if there is no proper placation of the deity involved. As the Igbo would say "ofu aka rutammanuyaezuooha" (if one finger gets oil, it extends to the others).

The Igbo traditional society had a fair and effective justice system, which ensures that justice is dispensed against an offense committed in the community. They were responsible for the judicial running of their various communities and clans. Achebe demonstrated this with the egwugwu ancestral spirits of the Umuofia. They preside over disputes as the trials were done with the judges and witnesses. They acted like a justice panel; they listen to complaints, make group decisions and pass judgments. In line with traditional knowledge of the ancestors which the egwugwu represent, the people respect the judicial system. There are also social control mechanisms that persuade people to adhere to the socio-ethical values of the traditional Igbo society and dissuade them from infringing upon them because the consequences could spell colossal doom.

The Igbo culture is rich in arts and crafts. Igbo material culture is given meaning through arts and crafts. Some of the decorative arts are designed to beautify things and make them look delightfully attractive. Decorative arts can be found on various items used by the people including musical instruments, weapons, household equipments, dresses, people's bodies and buildings. A typical example of decorative art is the wall paintings of egwugwu house by the women of Umuofia.

Stories, proverbs, idioms, myths, folktales, songs are embedded in Igbo scheme of communication and cultural life. Achebe masterfully engaged them and other direct Igbo words to demonstrate the complexities, uniqueness and richness of Igbo language. The language is an important element of Igbo identity with highly stylized speech pattern used in communicating the cultural heritage and values of the people. Moral and socio-ethical lessons are drawn from it as they are used for linguistic expressions and to inculcate and underline standard of behaviour among the members of Igbo community.

There are cultural festivals and ceremonies where people gather to celebrate and observe customary events, like marriages, burial, wrestling matches. Notable among them is the feast of new yam which is celebrated to give thanks to deities believed to be responsible for the bumper harvest especially, ala, the earth goddess and ifejioku, the god of yam. They may sing, dance and have merry as the occasion demands.

\section{The Role of Bearing Children}

The feminine gender by nature is sanctioned with the chief responsibility of reproduction. The female body is formed and fashioned by Chineke (God the creator) to carry pregnancy, give birth, breastfeed and nurture babies. They are biologically structured to reproduce humankind. The most important role of women in the Igbo religious culture is to bear children. Achebe describes the birth of a child "as a woman's crowning glory" [1] (p. 61). They are greatly valued and respected for the biological role of giving childbirth. It has been noted 
that "the fundamental purpose of womanhood in the society is motherhood. The birth of a child in Igboland is greeted with a shout of joy to announce the arrival of the newborn. Children bring joy to their parents and relatives" [6] (p. 1). In fact, one of the chief purposes of marriage in the Igbo traditional religious culture is for the continuity of the family linage. "This is why marriage in traditional Igbo is highly esteemed especially for procreation of life. Thus, infertility, childlessness and celibacy are always shunned while divorce or polygamy is always considered as a consequence" [7] (p. 6). The continuity of the society is basically dependent on reproduction. It is in this philosophical conceptualization that the Igbo give their children such names like Amaechila (let not the community go extinct), Ahamefula (let not my name get lost). If there is no reproduction of the offspring in the communities, succession would eventually discontinue, as a result the society will ebb away and cease to exist.

Women in Igboland are so mindful of this principal role that they become sorrowful if they could not bear children. The sorrow of a woman without a child is shared by all concerned-the husband, the family, the kindred, acquaintances and well-wishers. When it becomes difficult for a woman to bear children, spirited efforts are made to ensure that she gives birth or the effects of bareness is relatively cushioned. On the other hand, a woman that successfully gives birth to children feels fulfilled to have played her role as a woman. In fact, she takes pride to be a woman. As a hen protects her chicks, gathering them beneath her wings, Igbo women go out of their ways in protecting their children. An archetypal case of such women is Ekwefi, Okonkwo's second wife. She is a characteristic illustration of women that suffer a great deal in terms of child bearing. In her case, she gave birth to ten children and nine of them died at infancy, typically before the age of three. It becomes a very deep worry when fellow women like Obiageli, the husband's wife, had already given birth to three living and healthy children, whereas Ekwefi has no living child.

Following the loss of nine children, Ekwefi showered virtually all her love on Ezinma that she even swore an oath of defending her only living child against all the gods in the world. "Ezinma was the only child and the centre of her mother's world [1] (p. 61)". She often decides the type of food they will cook. Ekwefi the mother even gives her such precious and contentious delicacies like eggs, which children of her age were rarely allowed to eat because such food is believed to lure them into stealing. Even when Okonkwo at a time caught Ezinma eating eggs, and in his usual temperament, threatened to beat up Ekwefi if she attempts giving the girl eggs again, Ekwefi didn't stop. The love for Ezinma was so deep and the bond very strong. Instead of denying her eggs; it would rather be done in the comfort of her bedroom so that Oknonkwo will not know. Ezinma on the other hand, is so fond of her mother that she also calls her by her name Ekwefi, unlike other children that call theirs nne, which is mother. "The relationship between them was not only that of mother and child. There was something in it like the companionship of equals, which was strengthened by such little conspi- 
racies as eating eggs in the bedroom" [1] (p. 61). She loves her in a manner that she would not disturb her while sleeping; she would not allow her leave the house in the morning or follow her fellow children to go and fetch water without having her breakfast. It isrightly observed, "Children guarantee woman's respect and enhance her status in the community" [8] (pp. 168-169). Ezinma restored Ekwefi's motherhood and Ezinma accordingly, got a fair share of motherliness.

Put differently, Igbo women do not just give birth to children, they also love and greatly care for their children. In fact, children are treasured and valued because they are seen as the future and continued existence of the society. This reason clarifies the value attached to women as homemakers, helpers and potential mothers are the most valuable and greatest blessing in the society" [9] (p. 10). No human society can survive without women who are the divinely predestined birth givers. It is therefore, the prime role of women to bear children.

\section{Women as Children Educators}

Prior to the introduction of western education, which was facilitated by the western missionaries and their agents of colonialism, traditional educational method has been a way of life among the Igbo. Suffice it to say that in the Igbo traditional society, teaching as a form of education and formation of members was not a novel invention of western academic curriculum; rather it is a derivation of the traditional code of conduct as enshrined in the sum of omenala Ndigbo [10]. It has existed with the people since time immemorial. It is understandably on this note that the traditional method of education is further described in the following manner;

The indigenous education is the native or locally established pattern of passing and acquiring knowledge, skills, traditional norms and other values of the group from childhood to adulthood. It has existed and thrived side by side with the people right from time immemorial. It is passed from one generation to another and from elders to younger members of the group or community. It is a means of socializing younger members into the accepted pattern of the community life. In the main, it is passed by means of oral instructions and practical activities [10] (p. 180).

Consequently, in the traditional Igbo educational scheme, mothers are the nursery and primary teachers of their children. Inasmuch as children are said to belong to their fathers in the Igbo culture, though there are some parts of Igbo that trace matrilineal descent [11]. It is the principal responsibility of their mothers to educate them. Some of the mothers start talking to their children while they were still in the womb as fetus. The woman who has been saddled by nature to be the mother is the one that breastfeeds the baby. As the basic and closest caregiver, she is also the first and foremost teacher. From the period of breastfeeding she starts instructing the baby. The mother is the fundamental enhancer of the child's character. At babyhood, she stays more closely-tied to the 
child. She is the person the child recognizes more than other members of the family. In a typical polygamous family like that of Okonkwo, Obierika, Okoye, and Nwakaibie, children live in the same huts with their mothers, while their fathers live in separate huts.

For instance, in Okonkwo's compound are "low voices, broken now and again by singing, reached Okonkwo from his wives' huts as each woman and her children tell folk stories" [1] (p. 76). Children are mostly educated by their mothers through story telling where they learn a lot of things about man and his society. Like the type of story Nwoye's mother used to tell him and his siblings, stories of the tortoise and his wily ways, the bird, aneke-nti-oba, who challenged the whole world to a wrestling contest and was finally thrown by the cat, and the story of the Earth and the Sky. Ekwefi also told Ezinma the story of the tortoise and the birds as she equally educated her through storytelling. Mothers therefore, pass the cultural values of the society by means of oral tradition and moral instructions. Non-human characters like animals are always used to show morals, explain strange situations and natural phenomenon like creation, life, death and the changing seasons when they are not understood by science [12]. In their huts with their mothers, they learn a lot of things. They learn listening and speaking skills, how to be grateful and thankful, how to settle quarrels and resolve conflicts, how to negotiate and compromise, how to be friendly and sociable, how to be hardworking and productive. In fact, they are instructed in a manner that they will learn and acquire skills that will profit them for a lifetime. This is done through two major ways, oral tradition and practical aspects that fall within their training scope. The Igbo traditional society relied on this method as means of transmitting especially, intangible aspects of the religious culture and the maintenance of historical account.

As a gender sensitive society, they also learn how to execute domestic duties and carry out house chores based on their gender. As young men grow they will no longer be spending their time in the huts with their mothers, rather they will be spending more time with their fathers as the father prepares and grooms them towards becoming a man. There are some duties that are expected of male children. The young men like Nwoye, do the difficult and masculine chores like splitting of firewood and pounding of food. But the mothers nurture, educate and raise them to this stage.

The mother helps to acquaint her children with the customs of their (paternal) people. She will also expose them to aspects of her people's (the maternal) cultural practices if they varied somewhat with that of her husband's people. They are taught cultural norms and social ethics so that they can fit well in the society. Children in the community are seen as the representatives of their families, therefore they need to be well brought up in line with the community values, so that they will always present and represent the good image of their families. Mothers, therefore, ensure that their children will not dishonor the community values and bring shame to the family. In fact, mothers appear to be the best educators. 


\section{Religious Roles}

It has become a common consent that Africans especially, the Igbo are exceedingly religious. From cradle to grave religion plays a significant role in members' existential realities as the traditional Igbo society is typically a beehive of religious allied activities. In the dominantly religious Igbo culture, women are also imperative parts and parcels of the religion. They play diverse religious roles. They could function as deity, religious personalities and adherents. But more importantly, they do not just belong to the Igbo traditional religion as ordinary members; some of them belong to the group of authorities that play leading roles in the religious culture of the Igbo. It is described in African traditional religious milieu as "sacred specialists" [13] (p. 100). Specifically in Igbo traditional religious culture, it is called the "ritual symbolic persons" [14] (p. 133), while in other instances, they are addressed as "religious authorities" [15] (p. 269). Igbo women therefore belong to this office of the sacred specialists and religious personalities. Put differently, the women are also religious leaders in diverse areas of the Igbo religious culture. They are medicine women, priestesses, mediums, rain makers, diviners, etc. They share this position with their male counter parts. Thus the patrilineal based Igbo society that is laden with totems and taboos accommodates the place of women as sacred personages and religious leaders.

Women in this category are imbued with supernatural powers. In fact, the most powerful deity in Igbo religion is portrayed and represented as a woman. After the Supreme Being, the most powerful deity in the Igbo religious thought is a female god, Ala or Ani, the earth goddess. It is observed that, "Among the deities, the central figure is the Earth Deity-Ala." [16] (pp. 179-180). Ala is a supernatural female force. The earth goddess is the custodian of morality in the Igbo religious culture. Okonkwo inadvertently killed a clansman and for that reason committed a crime against the earth goddess, which made him to flee from the clan of Umuofia. Homicide, whether accidental or intentional is a serious offence against the earth goddess. The earth goddess is so powerful that if appropriate punishment is not exacted on an offence against her and the land properly cleansed, her vicious wrath might be unleashed on all the people and not just the offender. Describing the prominence place and role of Ala, it is observed that:

As Queen of the Underworld, she is connected with the cult of the ancestors. She is also responsible for public morality, and offences against the law are crimes against Ala who makes the law and by whom oaths are sworn. So Ala is called the unseen president of the society [13] (p. 49).

In other words, the male dominated Igbo traditional society is being ruled by a supernatural woman. As the unseen president of the society her influence is greatly felt in critical aspects of the people wellbeing and survival. Thus agriculture which is central to the socio-economic facet, the mainstay of traditional Igbo society is considerably weaved around the indispensable role of this same female force. 
In Things Fall Apart, Achebe captures the place of Ala in the following manner:

...Ani, the earth goddess and the source of all fertility. Ani played a greater part in the life of the people than any other deity. She was the ultimate judge of morality and conduct. And what was more, she was in close communion with the departed fathers of the clan whose bodies had been committed to earth [1] (p. 29).

Ala is believed to embowel some supernatural forces that sanctifies and makes it sacred and highly revered. The departed ancestors who occupy a prominence place in the Igbo traditional religious culture and accorded due respects and honour as the guardians and promoters of the community welfare and well-being are housed in the bowels of Ala. The mother earth plays the most important and influential role in the traditional Igbo society.

In a similar vein, female religious leaders are often consulted by members of the society to offer solution on spiritual matters. During the time of Unoka, a woman called Chika was the priestess of Agbala, the Oracle of the Hills and the Caves. Achebe describes her religious traits in this manner, "she was full of power of her god, and she was greatly feared" [1] (p. 13). Female religious personalities are so powerful and daring. Okonkwo who is rendered as anti-feminist, a very powerful man that beats women, could not stand against women in their religious roles. While Chielo, the priestess told the family that Agbala wanted to see her daughter, Ezinma, Okonkwo could do nothing but to plead and was even sternly warned as a minor by the priestess for merely pleading "Beware, Okonkwo! She warned. Beware of exchanging words with Agbala. Does a man speak when a god speaks" [1] (p. 33). It was indeed the voice of a woman but the words of a god. Chielo is a female but she represents a male god. As such women in the Igbo traditional religious culture possess cultic powers that make room for them to rule over men no matter how highly placed and powerful the men may appear. Any erring man that refuses to yield to their roles and rules as derived from the gods could be punished by the goddess and gods of the land.

\section{Cooking and Care-Giving}

The due proprietors of the kitchen and domestic chores in the traditional Igbo culture are the women, that is what the Igbo means when he says usokwunne (mother's kitchen). That is not in any way to suppose that their roles are limited to the kitchen, but the culture conceded them with that right and responsibility over other category of persons. They double also as caregivers. They care for their children and husbands.

One major reason Okonkwo beats Ojugo his third wife, was that she did not cook afternoon meal because she went to plait hair at her friend's house. The Igbo traditional society always frowns at a woman who cannot cook for her family. Cooking in the house is so important that it could lead to beating as exemplified by Okonkwo. To underscore its significance in the Igbo culture, Achebe unmistakably remarks that "Okonkwo was provoked to a justifiable anger by his 
youngest wife" (p. 23). In a bid to reprimand him, Ezeani, the priest of the earth goddess, Ani, who can be greatly considered as a custodian of the people's religious culture equally, told Okonkwo in explicit words "your wife was at fault". Any wife that abdicates her role and responsibility of cooking in the Igbo traditional society is considered to be provocatively faulty. The wives cook for the husband, children and relatives around. It is a consensus notion among the Igbo that; "the way to a man's heart is through his stomach". A wife can make so many requests while the husband is eating a sumptuous meal she offered him and the man will grant her request at times without a second thought.

They also pass on these skills over to the girl child. The girl child as a potential mother learns these domestic skills from the mother. Whereas the husband provides for the family, the wife takes care of the family. Perhaps, it is on this note of care giving that some women in the society are recognized and enjoyed being addressed as Odoziaku (care-taker of wealth). Men who run polygamous families have cooking schedule among the wives. The schedule is mainly for their husband. A wife may cook for four market days and another will take over, and it will continue to run in that to-do list order. After cooking, it is basic that the husband is served first as the head of the family.

In a typical Igbo traditional community like the Umuofia, women help themselves in the task of cooking during occasions. During the marriage event of Akwaugo, Obierika's daughter, the women especially from Okonkwo's family assisted in the cooking. They also contributed in donating the cooking items like baskets of coco-yams, salts, smoked fish, palm oil, including delegating their children to fetching water and firewood for cooking the food. The women did not only contribute for the cookery ingredients and other items, they also helped out in the proper cooking. That they helped with the needed ingredients and items, and went ahead to cook the foods, shows the extent women can go in cooking and caring for others. Through the role of cooks and care givers, women sustain and maintain the home.

Igbo women are known to be so kind and caring. They love, support and take care of their husbands, children and relations. They do not just take care of their own biological children; they also take care of other children around them especially those that are kept within their care. In the Igbo traditional society, a mother sees every child in sight as her child. When Ikemefuna was brought to Umuofia and the elders of the clan decided that he would for the interim be in the custody of Okonkwo, he handed him over to his first wife, the mother of Nwoye. Achebe remarks that "Nwoye's mother was very kind to him and treated him as one of her children" [1] (p. 22). Igbo women seem to be more caring than their men as seen in the case of Ikemefuna, who was put in the care of Okonkwo. Similarly, when Ojugo, Okonkwo's third wife went to plait hair at her friend's house and did not return early enough to prepare lunch. Nwoye's mother took her children and they ate together with her own children. Igbo mothers are quite accommodating, emotional and hospitable and have stronger bond with their children. They are extremely caring, nurturing and good cooks. 


\section{Economic and Supportive Role}

No man can raise a legitimate family in the Igbo custom without a woman. Before it becomes a family, there shall be one or more women who shall be foundational in the establishment of the household. The more wives, the more support a man gets in his family. Men who want to be rich and influential marry two or more wives in order to raise many children who will support in farm work and other economic activities. Typical examples of such men in Umuofia are Okonkwo, Obierika and Nwakibie. Nwakibie in particular was stupendously wealthy by every standard in the Umuofia clan. He has nine wives, thirty children and the next to the highest title which a man can take in the Umuofia traditional society and three rich bans. An individual with large family, coveted social or traditional titles and large yam ban is considered to be successfully wealthy in Igbo traditional society. The intimidating success of Nwakibie was made possible by the contributions of his numerous wives, who primarily gave birth to his children, nurtured them and greatly contributed to the economic activities that helped to enhance his high towering status in the society. It is in this light that the people would always say that "beside/behind every successful man, there is a woman". Women in this regard help in the reproduction of children that form the bulk of workforce of the family which helps a man to attain enviable economic and social status in Igbo traditional societies.

Igbo women also contribute to the economic wellbeing of their families by engaging in honest means of livelihood. A traditional Igbo society like the Umuofia is purely agrarian. Women are deeply involved in the agricultural practices as they plant crops, tend animals and weed the farms as at when due. In the Umuofia clan, women weed the farm three times at definite periods. Igbo women are not lazy or indolent; they are trained by their mothers to work hard and support their family. From the novel, it even appears that women can also fend for themselves and their children when their husbands seem not to be working hard enough or providing for the family. Such scenario played out between Okonkwo's parents. Unoka, Okonkwo's father is largely portrayed as a lazy man who could not provide for his immediate family. But Okonkwo's mother did not solely depend on her husband for sustainability. She and her two daughters "worked hard enough" [1] (p. 18) to ensure that there is always food on the table. They plant crops like coco-yams, beans, melons and cassava. They give constant attention to their crops. Igbo women support their husbands and contribute immensely to the economic wellbeing of their families.

\section{Bridge Building Roles}

Women in the Igbo traditional society are bridge builders. They connect one family, kinship and community to another through marital relationships. People who want to form allies or become part of a certain community or family do this through marriage relationships. As the Igbo would say "ogobuikwu" (in-law is kinsman). For political, economic, social or religious reasons a man may decide 
to go into a particular kindred or family and marry so that he can become part of the family. The family of the woman or the woman herself can also accept to marry a particular man of her choice for similar reasons. Ekwefi rejected her former husband and married Okonkwo because he is a famous warrior and a man of worth. Thus becoming Okonkwo's wife implies that his people are in-laws to one of the greatest men in the Umuofia society. Her association with Okonkwo expectedly brought her to limelight within the clan and made her a famous female character in the narrative.

Another important role of women in Igbo culture is their supportive role of providing succor and solace to their children through maternal family background. Though Igbo women are married out to other families and societies, they are still integral members of their nee and birth families. They are the great umuada of the Igbo traditional culture. The position of the woman as a member of her family of origin is not just recognized for ages, but extended to their children irrespective of where their mother got married and gave birth to them. There is an Igbo adage that says "Osochuwanwataebe a muruya, yaagbagaebe a murunneya" (if a child is being hunted among his kinsmen he runs to his maternal kinsmen). Okonkwo is a typical example of that adage. He ran to his mother's kinsmen at Mbanta, following his banishment in Umuofia as a result of murder. He was well received by his mother's kinsmen especially his uncle Uchendu and his children. Igbo largely traces patrileneal decent, but in a situation a person's life is threatened or at risk among his kinsmen, he seeks refuge and safety with his maternal kinsmen. Uchendu, Okonkwo's uncle corroborated with the above traditional notion when he told Okonkwo that:

It's true that a child belongs to its father. But when a father beats his child, it seeks sympathy in its mother's hut. A man belongs to his fatherland when things are good and life is sweet. But when there is sorrow and bitterness he finds refuge in his motherland [1] (p. 107).

In his motherland, Okonkwo was supported with the basic necessities of life for survival. He and his household were happily welcomed, given lands and treated like one of them. He did not experience any form of discrimination or prejudice from his maternal people. Rather, his mother's kinsmen helped him to build hut for himself and his three wives. This underlines the meaning of the Igbo name "Nneka" (mother is supreme). The place of the mother in the Igbo religious culture is of fundamental value. This is a position that man cannot afford except on the basis of maternal relationship. It is in this light that it is reiterated that "because womanhood is associated with life, sympathy, protection and affection, a woman is looked upon as the final refuge whether she is alive or dead" [17] (p. 352). Like a hen protects its chicks against all forms of harm, irrespective of the place and position of their father, so does a mother protect her children in Igbo traditional culture. A woman's role as a mother is institutionalized in Igbo traditional society and a man is naturally protected by it. Therefore, women build bridges and bring succor especially to their children when their paternal kinsmen fail them. 


\section{Significance of the Study in Promoting Social Progress}

The work implicitly underlines the fact that all human beings are born equal and different genders play different roles, as a result women should be respected. It helps to show how far the traditional Igbo women have evolved, establishing their presence and exerting their influence in a changing Igbo world. Since time immemorial, Igbo women have been key factors not just to the continuous existence but also to the advancement of the society. They have continued to be very diligent in their roles that they have been able to align with modern realities and developmental initiatives. Women in Igbo society have improved tremendously in every aspect of socio-cultural transformation. A number of them have acquired educational, economic, political, religious and social powers that are supportive to their roles and contributions to societal development. Igbo women are responsible and resourceful, assiduous and industrious, creative and productive. They constitute an integral component of the labour force. They essentially engage in the common welfare and running of their communities and towns. They are unswervingly involved in politics and government at all levels. As organized sets, the Igbo women act as one of the most effective pressure groups in the Igbo traditional milieu. For instance, the women wing of different Igbo communities especially, under the auspices of umuada (daughters) in Igbo traditional culture, always transmit impactful pressure on any act of misdemeanor and occurrences that they consider improper or against the general wellbeing of their people. Igbo women constitute a vital and viable force to the development of their society. They ensure that everyone conforms to the norms of the land including male members of the town. As such, this work will contribute in indicating the need for improved social engineering and helping members of the Igbo contemporary society to create enabling ground for interpersonal relationships that will allow male and female members to meet their needs and reach their full potentials in life.

This study will further help the Nigerian society and the Igbo group in particular to appreciate more the indispensability of women, in her quest to improve on all socio-cultural fronts and assert herself as a nation driving to the way of social progress. It will enable decision makers, researchers, political and community leaders, women leaders and other concerned bodies to always consider the place and roles of women in formulating policies and carrying out developmental initiatives. Such considerations will help to empower women socio-economically and bring about poverty alleviation and dependency mitigation. Drawing largely from the role of women as captured in Things Fall Apart, the work demonstrates that women are key players to making life easy and providing human needs. As such, in every matter of general concern, women should be duly consulted in order to tap from their ideas, abilities, and diverse roles while considering their position and needs tremendously imperative for social advancement. The development and progress of the society and wellbeing of the people is a general concern that demands the contribution of all members irrespective of age and 
gender. This will help to debunk erroneous concepts about Igbo women and slab the long existing social void created by such illusory notions like "women are to be seen but not to be heard in traditional Igbo culture". Rather, the need to galvanize both genders will be largely construed and prioritized in enhancing economic development and advancing social progress.

\section{Limitations of the Study}

As with majority of studies, the present work is subject to limitations. Consequently, in the current study, there are two major limitations that could be addressed in future researches. First, the study focused on Chinua Achebe's Things Fall Apart, therefore, the considerations and scope of analysis in the study is dictated by Chinua Achebe's position about women in Igbo culture as overtly captured in the novel. This greatly controlled and influenced the interpretations from the study. There is therefore, the need for further research on the role of women in the contemporary Igbo society that will be more data integrated.

Secondly, the study is based on secondary data, principally as derived from Things Fall Apart which was written over five decades ago. Therefore, the age of the main source of data could present a constraint in making current assumptions based on the novel. Consequently, the investigation was based on Igbo women, the findings may not translate to women of other ethnic nationalities. Future work therefore, should be expanded to involve a larger geographical area in analysis. The present work, however, underscores the valuable and indispensable roles of women in Igbo culture and forms the basis for future, broader and more inclusive studies.

\section{Conclusions}

The attempt here has been to use the novel and rebut some of the negative notions about women in the mind of a careless reader and indiscreet observer as also derived from the novel. One of such wrong notions is that Igbo men beat their wives. But as obtained in other human societies of the world, in the Igbo traditional society, it is only very few men who cannot control their anger like Okonkwo and Uzowulu that can beat their wives as typified by Achebe. This is because no mention was made about other men like Oboerika, Nwakabie, Uchendu among others about beating their wives. However, when a woman is beaten frequently by the husband, she can go back to her house. Women in Igbo traditional culture cannot be seen as robots or punch bags for their husbands. Though Okonkwo and Uzowulu tend to subject their wives to the status of robots by not always allowing them to have their say or beating them at the least provocation, it should also be understood that the culture makes a case against such suppressive and wife battering husbands. As exemplified in the case of Uzowulu and Mgbafo his wife. Uzowulu, a beastly serial wife beater, was also beaten blue and black by the wife's brothers. Mgbafo his wife and two children were as a result taken away from him. It took the mediation of the egwugwu 
elders for him to go to his in-laws with a pot of wine and beg for his wife's return. He was once more, strictly warned by the elders that "it is not bravery when a man fights with a woman" [1] (p. 75). Wife battening or domestic violence is therefore, not part of the Igbo traditional culture. Rather, it is seriously loathed and controlled through traditional moral principles as enshrined in the corpus of Omenala traditional custom. As a result, a woman who is frequently beaten by the husband or not happy in a marriage is supported by the culture to go back to her father's house and have her peace.

There is no gainsaying the fact that in the novel, Achebe painted a picture that instantaneously brings to thought that the dignity of women has been greatly undermined. As observed from the novel: women could be beaten by their aggressive husbands; Okonkwo, the protagonist of the novel is predominantly portrayed as a chief misogynist; one man can have multiple women as wives and they are awfully bound to pander to his whims and caprices; their contributions are largely dictated and limited by cultural traditions; they are not involved in core traditional discussions of their community; they are not constituent members of the ancestral egwugwu judicial council that make group decisions and pass judgments; they are restricted from a lot of cultural practices. In fact, women are largely portrayed by the narrator as corporally weak and obsequiously subservient to their men.

More so, the misogynous Okonkwo is the principal character in Things Fall Apart. Understandably, he is well versed in the cultural traditions of the Igbo as represented by the Umuofia community and fanatically passionate about it. Nevertheless, Okonkwo is chiefly characterized with apparent misogynistic traits that are quite antithetical to the Igbotraditional customs, which he appears to cherish and uphold. He distinctly displayed this feature of women despiser all through the narrative. Being an illustrious and celebrated personality in Umuofia and beyond, Okonkwo consequently developed into an inappropriate model and erroneously provided some negative impressions about the position and role of women in Igbo culture.

Therefore, a good analyst should be dispassionate, probe deeper and not out of sheer prejudice or contempt lose inherent sight of the critical roles and contributions of the womenfolk in Igbo traditional society as depicted in the novel. Inasmuch as the feminine gender is portrayed as weaker and their value underscored with a wide patriarchal veil, women play pivotal roles in the supposed hegemonic masculine culture. Eventually, the incessant negligence of Okonkwo to the feminine gender at every twist and turn paved way for his downfall. In due course, it led to his disgraceful end. In spite of the patriarchal nature of the Igbo society, the roles of the feminine gender are essentially indispensable and fundamentally central to the overall wellbeing of the male gender, the survival and continuity of the society.

\section{Conflicts of Interest}

The authors declare no conflicts of interest regarding the publication of this paper. 


\section{References}

[1] Achebe, C. (1959) Things Fall Apart. Heinemann, London, England.

[2] Nnadi, I. (2013) Son Preference-A Violation of Women's Human Rights: A Case Study of Igbo Custom in Nigeria. Journal of Politics and Law, 6, 134-141.

https://doi.org/10.5539/jpl.v6n1p134

http://www.ccsenet.org/journal/index.php/jpl/article

[3] Ugwu, C.O.T. (2014) The Demise of the African Gods: Fallacy or Reality. An Inaugural Lecture of the University of Nigeria, Nsukka, Nigeria.

http://www.unn.edu.ng/wp-content/uploads/2015/09/84th-Inaugural-Lecture-Prof. pdf

[4] Asadu, O. (2016) Amarachi Attamah: It Hasn't Been Easy, But We Have Succeeded. https://sheleadsafrica.org/amarachi-attamah

[5] Nwosu, H.N. (2002) Politics and Administration in the Igbo Traditional Society. In: Ofomata, G.E.K., Ed., A Survey of the Igbo Nation, Africana First Publishers Limited, Lagos, Nigeria, 413-424.

[6] Udeagha, N. (2014) Social and Moral Implications of Baby Factory in Abia State. Ph.D. Seminar Paper, Department of Religion and Cultural Studies, University of Nigeria, Nsukka.

[7] Oraegbunam, I.K.E. (2010) Crime and Punishment in Igbo Customary Law: The Challenge of Nigerian Criminal Jurisprudence. OGIRISI: A New Journal of African Studies, 7, 1-31. https://www.ajol.info/index.php/og/article/viewFile/57917/46285 https://doi.org/10.4314/og.v7i1.57917

[8] Nwoga, C.T.N. (2013) Socio-Religious Implications of Child Adoption in Igboland South Eastern Nigeria. Mediterranean Journal of Social Sciences, 4, 705-710.

http://www.mcser.org/journal/index.php/mjss/article/view/1564 https://doi.org/10.5901/ajis.2013.v2n11p168

[9] Ackley, D.G. (1962) The Male-Female Motif in Things Fall Apart. Studies in Black Literature, 5, 10-16.

[10] Udeagha, N. (2017) Changing Patterns of Indigenous Religious and Cultural Practices in Bende Local Government Area, Abia State. Ph.D. Thesis, University of Nigeria Nsukka, Nsukka, Nigeria.

[11] Agha, A.U. (2003) Religious Ethics in a Permissive Society. SAPS, Enugu, Nigeria

[12] Corrales, J. (2013) Folktales in Igbo Culture. https://prezi.com/cgttvyhzjnsy/folk-tales-in-igbo-culture/

[13] Parrinder, E.G. (1976) African Traditional Religion. Sheldin Press, London, England.

[14] Ifesieh, E.I. (1989) Religion at the Grassroots; Studies in Igbo Religion. Fourth Dimension Publishers, Enugu, Nigeria.

[15] Anyacho, E.O. (2005) Essential Themes in the Study of Religion. Niger Link Printing and Publishing, Obudu, Nigeria.

[16] Nwala, T.U. (1986) Igbo Philosophy. Litramed Publications (Nig) Limited, Logos.

[17] Samuel, E. and Chimeziem G. (2010) The Status and Role of Woman in Traditional Igbo Society as Presented by Two Nigerian Novelists. In: Ukagba, G.U., Obioma, D.O. and Nwankwor, I.J., Eds., The Kpim of Feminism; Issues and Women in a Changing World, Trafford Publishing, Victoria, Canada, 349-355. 